\title{
Universiteit
}

Leiden

The Netherlands

\section{Religion, reciprocity and restructuring family responsibility in the Ghanaian Pentecostal diaspora}

Dijk, R.A. van; Bryceson D., Vuorela U.

\section{Citation}

Dijk, R. A. van. (2002). Religion, reciprocity and restructuring family responsibility in the Ghanaian Pentecostal diaspora. In V. U. Bryceson D. (Ed.), Cross-cultural perspectives on women (pp. 173-196). Oxford [etc.]: Berg. Retrieved from https://hdl.handle.net/1887/9601

\footnotetext{
Version: $\quad$ Not Applicable (or Unknown)

License: $\quad$ Leiden University Non-exclusive license

Downloaded from: https://hdl.handle.net/1887/9601
}

Note: To cite this publication please use the final published version (if applicable). 


\title{
Religion, Reciprocity and Restructuring Family Responsibility in the Ghanaian Pentecostal Diaspora
}

\author{
Rijk van Dijk
}

The recent literature on the African diaspora devotes considerable attention to processes of identity formation, to representation of the community and to the logic of movement (Gilroy 1993, Holloway 1994, Akyeampong 2000). Similar studies in the anthropology of migration and globalization have begun to emphasize a transnational and multi-local perspective (Appadurai 1995, Glick Schiller et al. 1992, Basch et al. 1994, Clifford 1994, Shami 1995). These studies investigate how identities are formed in situations where, as a result of migration, diasporic flows and modern state formation, communities and neighbourhoods arise that seem neither to have a firm geographical anchorage nor to furnish the means for the production of the individual as a local subject: 'Actors who properly belong to a situated community of kin, neighbours, friends and enemies' (Appadurai 1995: 205). In modern processes of state formation in Africa and the West, the (labour) migrant, the refugee, the tourist and the traveller form indeterminate categories and localities. In one sense they may still belong to a particular nation state or society, but from another they remain uncaptured. Appadurai proposes that indeterminate communities of this nature should be termed 'trans-localities', and he calls for an anthropology that can deal with all such deterritorialized processes of identity formation (Appadurai 1995: 204, 213).

This perspective clearly moves away from the type of migration studies common in the 1970s and 1980s, which were dominated by what Rouse (1995) has called 'bipolar approaches'. They held that people moved between places that were fundamentally distinct in social, cultural, economic and political terms, that maintaining meaningful relations across 
such distinctions was a difficulty every migrant faced and that therefore two models of adaptation usually developed during the process of migration. One was circular with the migrant remaining attached to the place of origin; identification with the place of destination remained limited and the migrant returned sooner or later. The other was linear and the migrant became reoriented to the place of destination, sought permanent settlement and realised a change in identity.

This bipolarity has been largely amended by current studies that seek to understand the multifaceted networks and translocal spaces that migrants in present-day interactions appear to create through modern forms of communication, movement and information. Through continued movement back and forth and the increased circulation of money, goods, services and information, a compression of time and space has occurred leading to new kinds of social spaces which can be called multi-local sites. This notion, however, only slowly percolates into conventional migration studies, as Baker and Aina (1995) show.

This chapter examines one of the newly emerging, transnational, social sites that has developed in the process of intercontinental migration of Ghanaians abroad. The social space concerned is that of Ghanaian Pentecostalism, which in recent decades has developed both in Ghana and in migrant communities of Ghanaians in the West. This rapidly growing form of Christianity appeals predominantly to an urban and mobile population because of the international linkages and branches it has established outside Ghana, the entrepreneurial style of its leadership, and its emphasis on Western-oriented consumption styles and social relations. Likewise, in the migrant communities abroad, many Pentecostal Churches continue to propagate and support the multifaceted international (religious) networks through which they communicate with Pentecostáls either in Ghana or in the West. They are members of a larger transnational community and identify with a multi-local frame of reference.

In its project of delocalizing its subject, Pentecostalism restructures kinship relations and obligations. This chapter argues that its appeal is based on the opportunities it provides for bringing kinship obligations under the supervision of its individual members. It confronts the ancestral past of family authority, pursues a replacement of the authority of family heads, and seeks to implant conjugal relations, which it promotes as being part of a modern identity. Pentecostalism reformulates the hierarchical and obligatory gift-giving system upon which kinship relations are based. It subjects reciprocity to moral supervision while making it thoroughly multi-local. This is of particular significance in the diaspora where many migrants see themselves faced with the obligation to send money to relatives living at home and elsewhere. In restructuring such obligations, the Ghanaian Pentecostal Church located in Ghanaian migrant communities seems to be taking on surrogate family responsibilities, thereby communicating the message that a religious and moral control of such relations is at stake.

\section{Pentecostalism at Home and Abroad: Its Transnational Dimensions}

Pentecostalism has become the most popular form of Christianity in Ghana over the last 20 years. Between 1987 and 1992 the number of Pentecostal churches grew by as much as 43 per cent (Ghana Evangelism Committee 1993). Although there are many different forms of Pentecostalism, and not all are gaining popularity at the same rate; recent figures show a marked increase in the spread of Pentecostalism throughout rural and urban Ghana. The Church of Pentecost is one of the oldest Pentecostal denominations. According to the National Church Survey, it has now become the largest single Church with a steady adult membership of nearly 260,000 people belonging to just under 3,600 congregations. By comparison, the Presbyterian Church has a steady membership of about 180,000 divided across 1,900 assemblies (Ghana Evangelism Committee
1993 ).

Pentecostalism in Ghana has also been institutionalized through the founding of an umbrella organisation called the Ghana Pentecostal Council that serves more than 120 Pentecostal churches. Many of these churches belong to what became known as the 'second Pentecostal wave' that has swept across Africa since the 1970s, and has led to the emergence, particularly in the urban areas, of a newer, charismatic type of Pentecostalism. These Churches, such as Dr Mensa Otabil's International Central Gospel Church and Bishop Duncan Williams' Christian Action Faith Ministries founded in the late 1970s, attracted many members from the young and urban middle class who are seeking success and prosperity in life (Gifford 1994, 1998, Van Dijk 1997, 1999).

This popular second wave of Pentecostalism followed and continued a process that can be described as the indigenization of earlier missionbased Pentecostalism (Meyer 1995, Larbi 1995). Missionary Pentecostalism was introduced to Ghana during the first three decades of the twentieth century, and took root with the founding of Churches such as the Assemblies of God and the Apostolic Church, from England and the United States. Though sometimes viewed as belonging to the category 
of so-called spirit-healing Churches that emerged at roughly the same time (Wyllie 1980), important differences in terms of ritual discourse and practices meant that eventually Pentecostalism took a different path to these other independent Churches.

In terms of the various forms of Christianity, the Pentecostal Churches have engaged in a cultural dialectic on two fronts. They have challenged mainstream Christianity on the perception of evil, on the diabolization of key elements of African cosmology and on ways of counteracting witchcraft and evil spirits. Mainstream Christianity (Presbyterianism, Catholicism Methodism and Anglicism) has preferred to deny the existence of witchcraft (bayie) and has rejected the power of spirits (adze), amulets (asuman) and traditional healing practices as being mere superstition (Debrunner 1959). It has refused to accommodate or absorb any of the elements of African cosmology to save the pure faith from being contaminated by devilish and occult forces. The development of independent African Christianity and its diverse forms of spirit healing Churches can be interpreted as a process of coming to terms with the powers that mainstream Christianity denied and ignored, and as a way of providing individual members with healing and protection. Churches like the Nazarene Healing Church and the Musama Disco Christo Church included Christian doctrines and provided healing through a range of objects and substances that originated from ritual practices rooted in the veneration of abosom (family and ancestral spirits) and their worship through the shrine priests (okomfoo). The use of herbs, candles, oils, baths, concoctions, magical rings and the like were very much a part of this world and were included in the spirit-healing Churches' symbolic repertoires.

However, the Pentecostal Churches engaged in a second dialectic as

hey could not accept practices that would signal the continuation of a they could not and make the Church vulnerable to attacks from the Devil cultural past and make the Church vulnerable to attacks from the Devil and his many demons. Ancestral spirits, witches and ritual practices that related to veneration and protection were classified as demonic and were diabolized (Meyer 1992). A rigid dichotomy was developed distinguishing benevolent from malevolent powers and spiritual forces leaving no middle errain for ambiguity. Whereas ancestral deities (honhom ananom) can (n) either work for good or bad in the community or particularly in the family, in Pentecostalism, not denying their existence, their influence is equivocally brandished as malevolent. Healing and deliverance from such powers can only take place through the 'blood of Christ', the laying-on of hands and ecstatic prayer sessions in which the benevolent presence of the Holy Spirit is manifest through speaking in tongues (in Twi kasa foforoo, literally 'speaking the new language'). Objects and substances relating to a cultural past are not allowed within its ritual practice and discourse. In Pentecostal practice a great deal of attention is focused on fasting which is perceived as a way of arriving at a spiritual control and inspection of the 'belly' (yam) as the place where the ancestral spirits make their presence felt and influence the reproduction of society.

When the mission Pentecostal Churches started to Africanize around 1950 in terms of leadership and forms of worship, the importance of their own distinctive ways of dealing with evil forces in society grew. This approach was in stark contrast to mainstream Christianity which denied the efficacy of these forces and opposed the spirit-healing Churches' demonic practices. While the Pentecostal Churches were growing in strength, the spirit-healing churches became weaker, less appealing and increasingly less able to adjust to the changing fortunes of Ghanaian society as it entered a global system.

Although the older Pentecostal Churches were represented in Ghana's urban areas and could claim international links through their overseas branches, the new type of charismatic Pentecostal Churches made internationalism their hallmark (van Dijk 1997; Gifford 1998). In Accra and Kumasi, Churches were adding terms such as 'international', global' and 'world' to their names, thus promising religiously inspired access to transnationalism. ${ }^{1}$ Furthermore, this new Pentecostalism appears to have been strongly inspired by Pentecostal developments in America. Firmly located in the prosperity gospel, it propounds the notion of the individual's combined spiritual and socio-economic success. Leaders exude charismatic power and demonstrate their acumen in business relationships.

Another salient feature from the mid-1980s onwards has been these Churches' international self-presentation. The 'global claim' has become a prominent feature. It shows that, unlike most spirit-healing Churches, they can extend beyond Ghana, and Ghanaian and West African culture. Consequently, they have sought to enter other cultural contexts and have ascribed to them a place in their ideology, organization and subsequent religious experience. The claim is not simply that Ghana is "too small a place for our message', but that entering other cultural contexts deepens, enriches and essentializes the religious experiences of Pentecostal communities. Operating from Accra or Kumasi, these Churches began setting up branches outside Ghana, particularly in Western Europe and the US. Pentecostalism has connected with the new African diaspora through its message for a mobile urban population eager to participate in transnational movement. Over the last decade migrating to the West has become increasingly difficult due to stiff measures taken by many governments to curtail immigration from Africa. As Europe became a fortress, large 
numbers of Ghanaian Pentecostal Churches were establishing themselves in the continent's major cities, adding to Pentecostalism's international image and promise of success.

An estimated 12 per cent of the Ghanaian population is presently living abroad (Peil 1995) and the ambition of many young urbanites is to join the intercontinental labour migration. Pentecostalism in Ghana feeds into notions that many young people harbour about the affluence and desirability of living in the West. Major communities of Ghanaians can be found in the US, the UK, and in other Western European countries such found in the US, the UK, and in other Western European countries such as Germany and the Netherlands (Nimako 1993, Ter Haar 1994, 1998 , Attah-Poku 1996, Van Dijk 1997). These communities tend to maintain close links with Ghana and relatives living in Ghana, but also with one another as members of one family can often be found living in a number of Western countries as well.

Movement between these various communities is an important part of the new Pentecostal Churches. The Churches have connections with international Pentecostal circles that create an extensive exchange of people and materials both to and from Ghana. Conversely, some of the Pentecostal churches founded in the Ghanaian diaspora have evangelized their way back to Ghana. In other words, alongside Ghanaian-based Pentecostal Churches that have been set up among Ghanaian communities Penteraspora Pentecostal in Amsterdam, London or Hamburg, full-fledged diaspo. Pentecostalism has become a transnational phenomenon that, in its modern form, is locally expressed through a highly accelerated circulation of goods, ideas and people. It has formed a moral and physical geography whose domain is one of transnational cultural interpenetration created and recreated through travel and encounter.

There are approximately twenty-five Ghanaian Pentecostal Churches in the Netherlands where sizeable Ghanaian migrant communities exist, centred on Amsterdam, the Hague and Rotterdam (Ter Haar 1998). They centred in membership from 50 to 600 adults and include both legal and illegal migrants. In the Hague, which is the location of one half of my multi-sited research (the other being in Accra), eight Pentecostal Churches are currently operating in a community of (officially) 2,000 adults. $^{2}$ They hold an influential position in the community and function as a de facto moral authority over a wide range of matters pertaining to births, marriage, funerals and other rituals and arrangements. Three of these Churches have direct links with Churches in Accra while the other three were founded direct links with Churches in Accra while the of ritual practice, worship, the in the Hague during to what can be observed in the Accra Churches and therefore a deep sense of transnational continuity, global unity and exchange, and direct accessibility is created for the Ghanaian migrant. The fact that so many Ghanaian migrants adopt more than nominal membership in these Churches signals the profound relationship between the one and the other. In effect, Pentecostalism produces its own specific politics of identity - an identity separate and distinct from that of the host society. Furthermore, Pentecostalism expounds a moral supervision over one of the most immediate social circles for the production of a person's identity: the family.

\section{Family Relations, Migration and the Pentecostal Ideology}

Many families in Ghana perceive migration to the West of one or more of its members as a secure strategy for economic success and survival. This strategy is a departure from earlier colonial and post-colonial movements of labour migration in and out of the country. Much of twentieth-century Ghanaian history can be described as highly mobile. In the colonial period which lasted until the mid-1950s a great deal of internal migration occurred from northern groups moving to southern and central regions in search of wage employment in the emerging sectors of cocoa production, mining and urban industries. Large migrant quarters arose near cities such as Accra and Kumasi where the northern labour migrants settled and from there contributed to the growth of the urban areas and their economic success. Experiencing an economic boom during the $1960 \mathrm{~s}$, independent Ghana witnessed an influx of labour migrants of a more regional nature as labour migration, by Nigerians in particular, became unprecedented (Peil 1979, Sudarkasa 1979). During the 1970s, however, Ghana's economy, especially cocoa production and similar export-oriented activities, was hit hard by deteriorating world-market commodity prices. Massive outward movement began of Ghanaian labour migrants seeking their fortune regionally. Nigeria, by then a new, booming economy attracted and absorbed large numbers of Ghanaian migrants until 1983. However, during Nigeria's rapid decline in the mid-1980s, the country's rulers developed a new and violent policy of mass deportation of labour migrants. Hundreds of thousands of Ghanaian labour migrants were faced with expulsion from Nigeria but a return to Ghana with its weak economy was no viable option for them (Aluko 1985, Yeboah 1986). It was at this time that massive intercontinental migration began, leading to the establishment of Ghanaian migrants in New York and in European cities such as Hamburg, London and Amsterdam. Ter Haar (1998) shows 
that by 1996 the Ghanaian migrant population had become the largest group among all the officially recorded migratory movements from SubSahara Africa to Europe.

Among young men, the desire to participate in the migration wave became, and still is, all consuming. Almost everyone has some short or long-term plan to become woyayie (the one who 'has arrived' and has made it in life). Many undertake an assortment of odd jobs, try to borrow money from relatives and seek help anywhere they can in their efforts to migrate. The investments are enormous in terms of the money required for a ticket, for the necessary documents, and for the bribes that are usually involved in 'making the papers'. A young man or woman's departure is received with joy and excitement in spite of the serious hardships they are likely to face upon arrival in the West, especially in the case of illegal travellers. After a certain period of time, remittances are expected back home. Usually the recipients are not informed of the circumstances in which the income was generated in the West. Commonly a veil of disinformation is created to hide the fact that, after arrival in the West, life is indeed hard. Jobs are menial, and violence, intimidation and disrespect are the migrant's fate. Remittances are squeezed from only very meagre savings.

Failure to travel to the West, deportation, or lack of success in finding some sort of income once in the West, are all considered disasters. Deportation back to Ghana means the loss of the investment made towards the goal of seeking one's fortune in the West. In addition, there is a tremendous loss of social esteem, a perceived weakness in one's entrepreneurial skills, and a burden on the shoulders of one's family. The causes of failure are not only interpreted by Ghanaian migrants in terms of Western policies, practices and institutions, but are predominantly explained in terms of weaknesses in personal, spiritual and protective power. Somehow and somewhere other forces have been able to take hold of such a person's life. Often witchcraft originating from within one's own family is suspected. The family is the domain of both primary attachment and primary fear. Its powers ambiguously work for good and for evil. Pentecostal groups everywhere relate to these ambiguities and offer spiritual ways of dealing with them.

Many aspiring migrants in Ghana eagerly visit so-called Pentecostal prayer camps that specialize in removing the 'spiritual blockage' to success. Dozens of these camps exist throughout the country, each regularly visited by hundreds of people seeking redress for difficult situations such as illness, infertility, unemployment, and travel, visa and passport problems. The largest is the one at Edumfa, led by the 70-year-old prophetess Grace Mensah Adu, and which was visited by more than 75,000 people in 1997. Commonly, the camp leaders and their assistants investigate the person's past history and location in his or her family (Meyer 1998; van Dijk 1997). Evil powers may reside in the family, based on its ancestral past and ancestral veneration, which haunt the person into the present and 'pull him down'. Pentecostalism has gained a tremendous appeal in Ghana due, among other factors, to the so-called deliverance rituals it offers to spiritually break ( $a b u b u$ ) ancestral bondage (Atiemo 1994, Meyer 1998, Van Dijk 1997). The hope and belief is that after spiritual breaking the road will be open for the person to acquire the necessary documents to travel to the West. Through prayer and fasting under the guidance of leaders at the Pentecostal prayer camps, the stranglehold of evil powers will be broken and success and prosperity can be restored. Most prayer camps take a residential form. People stay for a number of days until they feel their personal power has returned. Many Pentecostal believers do not seek help from the family shrine priest (akomfo) who is responsible for the veneration of family deities. Instead, the spiritual help they obtain at Pentecostal camps offers disentanglement from such a priest and the strengthening of family relations in the spiritual world that he would prescribe.

Beside the desire to travel, find healing and protection, Ghanaians in Ghana and in the diaspora are attracted to Pentecostal Churches and their leaders for deliverance from two major family concerns. These include 'crisis rituals' that take place within the family in relation to marriages, births and deaths, and the exercise of moral control over reciprocal obligations towards the wider extended family (in Twi: abusua). Both have clear-cut transnational and transcultural implications and ramifications.

With respect to the first, the Pentecostal leaders seem particularly concerned with the creation of monogamous, conjugal but not necessarily equal relations between husbands and wives. This concern with marriage relations should be placed in the context of developments that have been affecting kinship systems as a whole, particularly those of the Ashanti, Ghana's largest ethnic unit (54 per cent of the entire population) and the one that also holds a dominant position in migrant communities. Developments in what is largely considered a matrilineal kinship system have been the subject of rigorous anthropological analysis for a long time (McCaskie 1995). Most studies are interested in the dynamism of the matrilineal kinship system including marriage relations that allow for considerable flexibility and individual freedom that render them highly adjustable to all sorts of changing circumstances (McCaskie 1995, Clark 1999). The 
institution of marriage in the matrilineal system of the Asante was of less importance than the place of the woman in her lineage. A woman and her children are the smallest unit (fie or oyafunu koro) that belongs to the matrilineage and is therefore subject to the authority of the matrilineal elders. Men would have little say in the affairs of the fie of their wives and this has been one of the greatest issues of concern, negotiation and conflict over past decades. The twentieth century saw substantial changes in what were once considered by anthropology the systemic characteristics of Asante kinship and marriage relations, due to intermarriage with other ethnic groups and the breakdown of the authority of family elders in the process of urbanisation, missionisation and colonisation.

Pentecostal ideology, in broad terms, proceeds along this trajectory of engaging with kinship relations and customary (marriage) practices and articulates a modernist discourse on these persisting issues. For most Churches and their leaders marriage relations form a domain of contestation with the family and the authority vested in the elders (abusua panyin) in what they see as a fight against backwardness and ignorance. Theirs is a modern faith that critically examines tradition and often portrays culture as blocking progress and prosperity. Pentecostal marriage rituals are therefore fully copied from the West, with the bride often wearing an expensive white wedding dress. Pentecostal leaders concern themselves with the minute details of the contractual arrangements that precede the official marriage, thereby assuming a great deal of the authority that customarily rests with the family elders. Pentecostal members are supposed to marry in a Pentecostal manner which offsets a great deal of customary ritual and subsequently has the effect of curtailing the dominance of the family, its ancestry and forms of ancestral veneration. For instance, although it is common to serve alcoholic drinks at wedding ceremonies to all guests, and alcohol is used to pour libation to the ancestors, in Pentecostal wedding rituals this is unacceptable. Whereas the traditional coming together of the families to exchange gifts marks the official status of the marriage, in Pentecostal Churches this exchange is called the 'engagement' and implies that the marriage is not yet complete and still has to be officiated some time later in Church. Pentecostal leaders are involved with the bride-payment, make enquiries about the marriage partners independent of the family heads who traditionally hold that right, and assume the authority to accept or refuse to officiate at a marriage. In other words Pentecostal leaders have appropriated and at the same time replaced a great deal of the authority for their members that otherwise would have rested with the family elders and that other, mainstream Churches often still fully respect.
This contestative replacement is even stronger when the marriage is transnational and one partner lives in Ghana and the other in the Netherlands or in some other country. Pentecostal leaders use their international links within the global Pentecostal network to make enquiries about prospective marriage partners (whether they have been previously married, have children, their residence status and so forth). Through modern means of communication and their international branches they are often in a much better position to make such enquiries than the family elders of both marriage partners would ever be able to do. For these reasons, marrying in a Pentecostal Church in Ghana and in the diaspora has become a status symbol, a mark of genuineness and trustworthiness and, above all, a mark of modern personhood, a modern identity underlined by expensive, Western-oriented consumption styles. This identity is further strengthened by the fact that marrying in a Pentecostal Church signals a certain distance from family obligations, ritual and authority. It exemplifies a kind of appealing independence that has become highly valued by the younger generation.

Once the marriage has taken place, most Pentecostal Churches continue to engage with the couple by stressing the kind of conjugal relationships that keep the backward family obligations at bay. One aspect of this ideology relates to the investments that the man and wife will make for their old age. The Pentecostal Churches tend to stress that true Pentecostal couples should make no secrets about each other's income, and that savings and investments from these incomes should be for the benefit of both partners and their children. This ideology follows some of the laws that the Ghana government implemented in the 1980s decade affecting customary family inheritance rules. These laws, generally known as the Intestate and Succession Laws, were passed by Parliament in 1985 and validate rules of inheritance that prevent the matrilineage from taking hold of the man's property when he dies (Awusabo-Asare 1990). In Ghana's predominantly Asante matrilineal family system, inheritance would follow the line of the mother's brother. Ego would inherit from his mother's brother and not from his own father. The new laws, however, have put in place a defence for any man to ensure that his own children and not the nieces and nephews from his sister's side will inherit his property. In other words, these laws strengthen the conjugal relationship against the interest of the wider extended family. Pentecostalism has taken up this issue and carried it much further as an ideology to the control of family expenditure. Each conjugal unit is expected to spend one tenth of its net income on the Church (the so-called Biblical law of tithing). All other expenses are considered subservient to this. Only when tithing has been closely adhered 
to can the Pentecostal believer be assured that gifts to his wider family are sanctioned. In the following section I will explain how and why gifting is considered morally and spiritually hazardous by most Ghanaian migrants.

In addition to responsibilities towards the wider family, most couples also have other financial commitments. Usually each makes investments in plots and houses separately (Van der Geest 1997, 1998). In this way if a marriage breaks down, the partners will have their own investments to fall back on and their own means to accommodate and help other family members and their own provision for old age. While, in this sense, this is a guarantee which is highly common in Ghanaian society, Pentecostal leaders and Churches argue against these practices. Such independence in their view encourages divorce and other marriage problems. (In the Hague many consider marital affairs as one of the most pressing problems of migrant community life.) Women are considered by leaders (often men) as the weaker members of the conjugal couple spiritually, the most easily deceived by Satan, and the most vulnerable to occult attacks emanating from within the family. According to Pentecostal ideology, the man's position as head of the household should entail having access to, and control over, his wife's possessions and investments, which runs against the grain of a matrilineal family system. In the migrant community of the Hague, men feel especially dependent on their wives, not because of a transnational transposition of the matrilineal kinship system but because in many cases their permit allowing them to reside and work legally in the Netherlands is dependent on that of their wives. ${ }^{3}$ In this context, Pentecostalism recompenses men for what they perceive as a loss of power brought about by the Dutch legal system.

Another way of understanding the Pentecostal emphasis on conjugal relations concerns gifting relations to the extended family. Whereas much of the power of the matrilineage and its elders appears to have been diminishing in past decades, the notion of living under the obligation to give (especially money) to one's close relatives persists remarkably. To a great extent, kinship relations and a person's connection to a family are dictated by reciprocal relations, much more so than in any other domain of life. Almost by definition, family means the people one maintains reciprocal relations with. Structuring of family relationships and family obligations along money lines developed as part of the monetization of important aspects of Ghanaian social and ritual life in the late colonial and present post-colonial situation (Arhin 1995, Manuh 1995, Mikell 1995, Van der Geest 1997, 1998, Senah 1997). One of the important reasons for money becoming the marker of family relationships is its deterritorialized quality. Paying respect to the family elders and the ancestors traditionally was, and still is, a highly territorial act marked by pouring libation on the ground or on a specifically designated spot, money can be sent from any part of the world as a sign of paying homage to those that deserve respect (Van der Geest 1997). Money (sika) may intentionally and above all work as a conduit for the powers that emanate from within the family: sika ye mogya. This is borne out by the saying 'money is one's blood'.

Through tightening conjugal relations, Pentecostal leaders hope to delimit reciprocity. Conjugal relations help to control and supervise gifting, not only in material terms but also, and more importantly, in spiritual terms as $I$ argue in the following section.

\section{Dangers of the Gift}

One of the most important concerns of Pentecostal Churches and their members in the diaspora is the obligation to give, to remit money back home usually to one's mother and sisters. This section focuses on how this positions the Pentecostal believer within the gift economy of the Church, and within Dutch society.

The development of intricate gift systems in migrant communities is certainly not a unique phenomenon; nonetheless the cultural, moral and situational features of the Ghanaian Pentecostal discourse and practice warrant analysis in their own right. Through fasting, ecstatic prayer sessions, deliverance rituals and home cell meetings, an agency is constructed that, in ideal terms, should be able to control, supervise and inspect the gift-giving relations with the family back home. At first glance the aim of Pentecostal ritual practice appears to be the creation of individuality by cutting ties with the family, by controlling the 'belly' (yam) such that the influence of the ancestors is curtailed, and by organizing funerals, weddings and birthing ceremonies that replace traditional practices and reduce the influence of family elders. The roots of this concern and how it relates to gifting can be traced by looking more closely at practices of the charismatic Pentecostal Churches in Accra and their concepts of the gift and subjectivity. In one of these Churches the following event happened:

On a Sunday in November 1996, Pastor E. of the International Bible Worship Centre (IBWC) at Kokomlemle in Accra explained to me that he had received a lady for prayers who asked to be cured of her infertility. She had been unable 
to conceive and she suspected that the problem was caused by panties that had been given to her by her mother-in-law. Pastor E. explained that this lady had given testimony to a congregation of more than $\mathbf{5 0 0}$ members at the central Sunday meeting in which she recalled the fact that her newly wedded husband was supposed to give money to his mother (her mother-1n-law) and that the mother fornicated spiritually with her son. The son was therefore unable to refuse giving to his mother despite trying to stop redirecting his attention fully to his wife, in accordance with Pentecostal ideology. In laying-on of hands the pastor revealed that there was a spirit of envy (bayie) included in the gift of the panties which the lady initially wore without a second thought. On advice and after being prayed for by Pastor E., she returned the gift to her mother-inlaw, unmistakably a daring and highly confrontational act, and with it the evil spirit of envy went. She is now expecting a baby.

This short story encapsulates in a nutshell the complexities of gift giving, desire, morality and family relations. It is typical of many that are told in the narrative form of testimonies, chronicling how difficult it is to become a modern individual no longer subverted to the powers that govern the family, the house or fie. Manifestly, this story refers to the importance of the gift in terms of capital formation and distribution within the confines of the family. The family, specifically its smallest unit, the fie, is tested on the basis of the efficacy of the gift. The father's and husband's responsibility is largely determined by giving money to his wife and children for clothes, school fees, medical care and so forth while the maternal part of that care exists in the reciprocity of food production, cooking and the selling of agricultural produce (and with regard to her husband, the reciprocal rendering of sexual pleasure).

As Clark (1999) shows, since independence and with the mounting costs of such expenses and particularly that of food, the husband's income has gradually become a gift of 'chop money' required to meet the basic needs of the family but from which his wife could no longer hope to save and accumulate for all other types of expenses. This rising inflexibility became critical during the late 1970s and the early 1980s just prior to the implementation of economic reform policies and structural adjustment programmes. Wives increasingly became direct rivals of their mothersin-law and their husbands' sisters to whom they were supposed to entertain gift-giving relations while facing decreasing financial resources of their own.

Gift obligations towards both the nuclear family and the extended family therefore have become a widely shared and hotly debated issue in Ghanaran society as interests of different matrilineages constantly collide. A husband's responsibilities towards his wife and his biological children run counter to his responsibilities as a wofa (maternal uncle) with regard to his sister's children who all belong to his mother's lineage. As Clatk shows, these conflicts, negotiations and imbalances have been exacerbated by men's current inclination to invest in the fie of their wives rather than in their sister's children. Family elders have heightened their pressure in retaliation and women are caught in between. The strengthening of conjugal ties implies that they are obliged to give financial assistance to the husbands' mother as well, something that, under customary kinship notions, would have been out of the question.

Pentecostal leaders address these issues and the ambiguities of being entangled in inseverable obligations towards the extended family (abusua as distinct from fie) through deliverance rituals. Deliverance rituals heighten members' awareness of the notion that real progress in life can only be made when one has the audacity to sever ties binding them to the family and its past. A person's past is interrogated and investigated and a complete break with the past is promoted as a safe route for escaping bonds with an ancestral past (Meyer 1998, Van Dijk 1998, 1999). People are often asked to fill out extensive written questionnaires dealing with a variety of aspects of their past lives, particularly events which symbolically mark their position in the family and its family history. For example, a person can be given certain statues, god objects, markings and incisions on the body, certain concoctions to drink, baths to take or medicines to take with their food. Gifts may signal the presence not only of kinship obligations but at a deeper level the ties that bind people to their ancestral past.

It is through the ancestral past, kept alive by rituals of veneration by the family shrine priests (akomfoo), that curses (nnomee) become manifest in the present. Certain gifts, such as eggs, are signifiers of that ancestral past and ancestral curses. They are considered food for the ancestral deities, which should be broken and poured to invoke their presence 'and make them eat'. Ancestral spirits and the curses that may have been concocted in the past through their interference usually manifest themselves through or in the belly (yam), the metaphoric place of metabolism and reproduction of the extended family, somewhat like an egg. In the story cited above, what was manifested was the evil spirit of bayie, loosely translated as witchcraft but in essence a force that precludes individuality and disentanglement from the family and its belly. Infertility resulted but the deliverance from the gift in the hands of the Pentecostal leader restored the desired individuality and a breaking (obubu) of those ties. The gift was brought back under the control of the person instead of the other way round. 
Deliverance forms the most essential ritual in Pentecostal practice (Meyer 1998; van Dijk 1997, 1998, 1999). Many Pentecostal Churches such as the IBWC have special deliverance teams, deliverance hours and produce special magazines in which deliverance testimonies are recorded. Gifts, giving and receiving play a substantial role in these narratives of ordinary people, members or clients of Pentecostal healers. In these stories one notices that there is a sudden realization that the gift is not free, not empty but imbued with intentions, messages and obligations, all of which the person would not have discovered if he or she had not been a Pentecostalist. The Pentecostal ideology, therefore, informs people of the ambiguities of the gift, exposes its history, its intentions and messages and prepares it for alienation so that it can be returned, disposed of or destroyed, ${ }^{4}$ which is often seen as an act of contestation.

Among Pentecostal members in the diasporic Churches, many hours are devoted to instructions by the Pentecostal leaders on how to give, when and how much, whom to trust in remitting money and, above all, how to combat the curses that may be part of these politics of the gift. Living in the West means that many feel especially vulnerable to witchcraft attacks from jealous kin and therefore in need of the special charismatic powers that Pentecostal leaders may wield over their lives. Couples take their advice and hours of counselling to heart. One such couple in the Hague for instance explained that for this reason they started 'cross-giving'. Whenever the financial situation allowed it, the husband would send $€ 50$ to his wife's mother and she would do the same for his so that devotion and attention are shared in the hope that jealousy and envy, always the source of witchcraft, would not arise from either of the two mothers and their families.

However, in addition to inspection and moral supervision of the reciprocal relations and the remitting of money, Pentecostalism seeks direct replacement when gifting relates to capital accumulation within the family. Paradoxically, although Pentecostalism appears to display a type of individualistic ideology for its members, by stressing conjugal relations and with supervision of reciprocal relations, in certain circumstances the interest of the family still prevails. The prime moment of family interest in any Ghanaian migrant's life is when death occurs among his or her immediate kin. Death is not only a social and emotional catastrophe but is also the single most important moment for the elaboration of the gift economy as a major form of capital accumulation (Arhin 1994: 312, Manuh 1995). The family's representatives living in the West take on a crucial position. They have the formidable responsibility of turning the funeral celebrations into a profit-generating operation. This is a responsibility that even the most confirmed Pentecostal member has great difficulty denying or ignoring.

Generally when a relative dies either in Ghana or elsewhere, kin living in the West are expected to organise funeral parties on behalf of the family in Ghana to contribute towards the costs, debts and financial obligations they have to meet. Usually some time after the actual burial a lavish party is organized with dancing and highlife music to which members of the migrant community are invited. In the Hague, often hundreds if not thousands of Ghanaian migrants, not only from the Netherlands but from other European countries, show up dressed in their finest clothes to pay their respects to bereaved family members and enjoy the social occasion. The party takes the form of a gift-giving event whereby everyone is supposed to donate substantial amounts of money to the family. Organized in the form of a type of contest, amounts donated by individuals may vary between $€ 25$ and $€ 2,500$. Money is the symbol of status and power, and the names of money givers are proclaimed together with the amounts donated. These gifts are a way of showing one's relationship to the family of the deceased and one's standing in the community as a whole. The expectation is that reciprocal relations are established or entertained so that when death occurs in one's own family a time of cashing in on the 'seed-money' can be held. Arhin describes the present-day situation in urban Ghana of these prospective reciprocal relations:

Donations . . compel reciprocal donations; habitual failure to attend funeral gatherings and make donations evokes its own punishment in the boycott of one's funeral performance by the community. (Arbin 1994: 313)

This compelling function of the gift-economy is well recognized by the migrant community. Such gift parties go on throughout the night and often end with donated amounts ranging from Euro 25,000 to 50,000. Having deducted their expenses, the remainder is then sent to Ghana: free profit without any taxation makes the gift-economy a royal road to capital accumulation. At other locations in the West the same will also be repeated so that the family among whom death has occurred is able to raise substantial funds, which are then largely controlled by the matrilineal family head (abusua panyin).

The Pentecostal Churches in the diaspora, particularly the Churches located in the Hague, have, however, all been active in creating their own morally supervised domain for such funeral exchanges. For members in whose families death has occurred these Churches have taken on the task of organizing funeral parties. Visited by hundreds of members of Ghanaian 
communities in the Netherlands and abroad, and irrespective of membership of the church, donations are equally impressive and contribute substantially to the family's wealth back home.

There are, nevertheless, a number of major differences with the secular version of this important family ritual and its economy. During the secular celebrations alcohol is served (the 'Schnapps' as they are called which preferably consist of Schiedam jenever) and it is used to pour libation in honour of the ancestors of the family. Through pouring of libation the ancestors are invited to 'come and drink' ( $n s a)$ so as to include the deceased in their spiritual realm. Pentecostal Churches have ostensibly moved away from this practice. If a funeral party is organized by a Pentecostal in and through the Church there will be dancing and music but no alcohol will be served, and above all no pouring of libation will take place. Its message is clear: reciprocity is crucial for social relations, for the building of a social safety net and for the survival of the family in Ghana, but it requires safeguarding against malevolent influences that the ancestral past of any family may harbour.

An advantage of organizing the celebration in a Pentecostal way is that it reduces costs and expenditures for the people responsible for its organization. The fact that no alcoholic drinks are served leads to higher expectations of profit.

During the Pentecostal funeral celebration the donated money is constantly prayed over by the Pentecostal leaders thereby purifying (Twi: nteho) whatever may come along in terms of evil powers in such gifts. In other words, Pentecostalism debates the ambiguities of such gift-giving events and makes its members aware of the hidden dangers that lie in receiving and passing on such donations. The Pentecostal believer is expected to control the donation morally so that the inverse will not occur imbuing the donation with powers that control the believer.

When a person dies while living in the West, those travelling home carry fingernail and haircuttings of the deceased, which will be buried at the place of birth as a sign of homecoming. The charismatic powers of the Pentecostal leader are expected to grant spiritual protection to those who are the bearers of bad news and to provide protection against witchcraft attacks from the family they need to visit.

Hence Pentecostal funeral ritual replaces the funeral rituals commonly organized by family elders and therefore grants its members the opportunity to accumulate through the gift-giving economy in a way that is beyond the control of these elders. Although the purpose of Pentecostal funeral ritual is the same, namely capital accumulation within the family at a time of crisis, the spiritual sanctioning of who is in control, who is supervising the establishment of reciprocal relations and who is inspecting the powers that may be imbued in its functioning are very different. The Pentecostal leader becomes a mediator and a true ritual broker who is usually engaged on behalf of his followers challenging the authority of the family elders. In other words, theirs is a discourse that acutely makes its members aware of the relationship between religion, reciprocity and the restructuring of family responsibilities in the Ghanaian diaspora.

\section{Conclusion}

There is a profound spiritual side to the migration of Ghanaians to the West, which so far has been little explored (Van Dijk 1997, 1998, 1999). The relationship between Pentecostalism and intercontinental migration is broad and multifaceted. Charismatic powers provide protection, success, wealth and prestige. Despite increasingly inhospitable immigration procedures and identity politics generated by many Western states, a great number of Pentecostal Churches display their success in being able to become established in the West and adeptly negotiate their way back and forth in transnational flows of people and capital. The relation between religion and mobility is, however, far from new and Pentecostalism, in a way, appears to build on much older Ghanaian (or perhaps Akan) traditions of travel protection and security cults (Werbner 1989). In other words, the Pentecostal ideology of breaking away from family tradition and bondage as a way of liberating the individual and making him or her fit for travel should in itself be historicized as belonging to a much wider cultural pattern. One of religion's major functions, to put it boldly, is after all the growth of personal power, the tumi as it is called, that is sought to achieve success, prosperity and social esteem in life; a desire widely displayed by many in present-day Ghana. Travelling to the West requires religious strength; tumi is of central concern.

What Pentecostalism, however, has done is to replace all kinds of medicines, potions, baths, statues and incisions with an emphasis on prayer and fasting as a strategy of spiritual inspection and introspection. Pentecostalism appears to continue a cultural pattern in which the migrant is included in a protective religious domain. Interestingly, however, Pentecostalism in the diaspora does not construe this domain as a continuation of Ghanaian or Ashanti culture per se, but as a means of affording a critical distance from it. Social science may see continuities, most Pentecostal leaders, however, emphasize discontinuities The Churches' identity politics are not those of custodians of Ghanaian cultural traditions in the West. Indeed the opposite is true as modern personhood is stressed, 
sanctioning the pursuit of wealth and prosperity in the West without submissiveness to family obligations that cultural traditions prescribe.

At the same time, and perhaps somewhat paradoxically, family relations still play a dominant role in most migrants' lives. There is a constant moving back and forth vis- $\grave{a}$-vis one's family, and the pressure of family obligations is felt strongly. Pentecostalism addresses the ambiguities that arise from this: on the one hand the breaking away from the family's ancestral past, while on the other hand still feeling responsible for family survival and doing the best one can as a migrant to remit money back home. Despite their ancestral past, for many Pentecostal believers, the family remains an important source of social security in the long term, even for those in the Netherlands, who on the basis of a legal residence permit may have access to state social security schemes. This notion of the family in terms of social security is even stronger for those residing illegally in the country.

Opposition to the family's ancestral past and the dangers that therefore reciprocity may entail should be interpreted as a discourse and a deliberate strategy towards Christianizing the family. Through Pentecostalism, Christianity appears as a new religious domain of superior power, more forceful than any of the other religious forms that provide security, protection and success (see Field 1960, Fortes 1975, McLeod 1975). This implies a thorough delocalization of identity, that is an identity that is no longer grounded in a specific, circumscribed locality of the family. Whereas the pouring of libation in honour of the ancestors literally takes place by pouring 'schnapps' on the ground, or by breaking an egg on the floor, Pentecostalism offers a much wider transnational frame of identification. For its healing and protective rituals it does not rely on herbs, plants, water, concoctions, baths and so forth, which other religious forms employ in the fabrication of their security 'medicines' and which all stress the notion of the individual being tied to a specific context, locality or even territory. Pentecostalism claims that healing and protection take place through prayers and fasting, activities that do not require a specific attachment to place and locality.

The relationship between Pentecostalism and migration can be best understood in terms of the internal strangerhood that is created. Other protective and security rituals emphasize the fact that a person, through migration, leaves a certain circumscribed locality where the benevolent influence of the family ancestors reigns and therefore must face the unprotected status of being a stranger elsewhere. Transnational Pentecostalism is appealing to many because it creates the notion that, although a migrant may travel abroad and take up residence in another cultural domain, the true believer still remains within its wider protective circle. Leaders of Pentecostal Churches, particularly in the diaspora, are often spoken of in terms of abusua panyin (head of the family), and clear signs of attachment to the leader are deemed necessary like small gifts, tithing, and consultation. As was discussed in the context of marriages, the leader is consulted on a range of issues by many migrants, sometimes even taking decisions on their behalf, settling family disputes, assisting in arranging funerals, and dealing with the authorities when necessary and asked to do so. He takes on what, in ideal terms, could be expected from a Christianized family, leaving all propensities to jealousy and envy towards his wealth and prestige behind so that witchcraft, the ultimate power of individuality, will have no place.

As Amin (1995) indicates, most migration studies a priori perceive of the migrant as an individual, an ordered person who takes decisions, makes choices and possesses an identity. This chapter has demonstrated the process of construction and fabrication of individuality that the Ghanaian migrants are involved in. Individuality, particularly in terms of attachment or detachment from the family and its obligations, rests only in the making and therefore needs to be problematized. Individuality cannot be assumed but is constantly being articulated and negotiated, and its contradictions are played out within the context of the Pentecostal churches. Vis-à-vis the family, the need for greater individuality is stressed and an enticing picture of modern personhood is presented that clearly evokes the imagery of a Western-styled person. At the same time, in the diaspora, the very same Pentecostal Churches create new domains and strategies of attachment so as not to become entirely engulfed in Western lifestyles. After all, the West remains a rough place where immorality in terms of sexual permissiveness, violence, hostile identity politics and criminality runs high. Pentecostal internal strangerhood is a project aimed at creating a critical distance both from Ghanaian culture and its powers, and from a Western world where one's personal powers again may easily run short of protection and security.

\section{References}

Akyeampong, E. (2000), 'Africans in the Diaspora: The Diaspora and Africa', African Affairs, 99(395): 183-215.

Aluko, O. (1985), 'The Expulsion of Illegal Aliens from Nigeria: A Study in Nigeria's Decision-making', African Affairs, 84(337): 539-60.

Amin, S. (1995), 'Migration in Contemporary Africa. A Retrospective View', in J. Baker and T.A. Auna (eds), The Migration Experience in Africa, Uppsala, Nordiska Afrikainstitutet. 
Appadurai, A. (1995), 'The Production of Locality', in R. Fardon (ed.), Counterworks: Managing the Diversity of Knowledge, London, Routledge.

Arhin, K. (1994), "The Economic Implications of Transformations in Akan Funeral Rites', Africa, 64(3): 307-22.

Arhin, K. (1995), 'Monetization and the Asante State', in J. Guyer (ed.), Money Matters: Instability, Values and Social Payments in the Modern History of West African Communities, London, James Currey.

Atiemo, A. (1994), 'Deliverance in the Charismatic Churches in Ghana', Trinity Journal of Church and Theology, 4(2): 39-41

Attah-Poku, A. (1996), The Socio-Cultural Adjustment Question: The Role of Ghanaian Immigrant Ethnic Associations in America, Aldershot, Avebury.

Awusabo-Asare, K. (1990), 'Matriliny and the New Intestate Succession Law', Canadian Journal of African Studies, 24(3): 1-16.

Baker, J. and Aina, T.A. (eds) (1995), The Migration Experience in Africa, Uppsala, Nordiska Afrikainstitutet.

Basch, L., Glick Schiller, N. and Szanton Blanc, C. (1994), Nations Unbound: Transnational Projects, Postcolonial Predicaments and Deterritorialized Nation-States, Reading, Gordon \& Breach.

Clark, G. (1999), 'Negotiating Asante Family Survival in Kumasi, Ghana', Africa, 69(1): 66-85.

Clifford I (1994), 'Diasporas', Cultural Anthropology, 9(3) 302-38.

Debrunner, H. (1959), Witchcraft in Ghana, Kumasi, Presbyterian Book Press.

Field, M.J. (1960), Search for Security: An Ethnopsychiatric Study of Rural Ghana. London, Faber and Faber.

Fortes, M. (1975), 'Strangers', in M. Fortes and S. Patterson (eds), Studies in African Social Anthropology, London, Academic Press.

Ghana Evangelism Committee, (1993) National Church Survey, Accra, A.G. Literature Centre.

Gifford, P. (1994), 'Ghana's Charismatic Churches', Journal of Religion in Africa, 24(3) 241-65.

Gifford, P. (1998), African Christianity: Its Public Role, London, Hurst \& Company.

Gilroy, P. (1993), The Black Atlantic: Modemity and Double Consciousness, London, Verso.

Glick Schiller, N., Basch, L. and Blanc-Szanton, C. (1992) Towards a Transnational Perspective on Migration: Race, Class, Ethnicity and Nationalism Reconsidered, New York, New York Academy Series.

Holloway, J.E. (1994), 'Time in the African Diaspora: The Gullah Experience'. in J.K. Adjaye (ed.), Time in the Black Experience, London, Greenwood Press.

Larbi, K. (1995), 'The Development of Ghanaian Pentecostalism: A Study of the Appropriations of the Christian Gospel in Twentieth Century Ghana Setting', unpublished $\mathrm{PhD}$ thesis, Edinburgh, University of Edinburgh.

Manuh, T. (1995), 'Changes in Marriage and Funeral Exchanges in Asante: A Case Study from Kona, Afigya-Kwabre', in J. Guyer (ed.), Money Matters.
Instability, Values and Social Payments in the Modern History of West African Communities, London, James Currey.

McCaskie, T.C. (1995), State and Society in Pre-Colonial Asante, Cambridge. Cambridge University Press.

McLeod, M., (1975), 'On the Spread of Anti-Witchcraft Cults in Modern Ashanti', in J. Goody (ed.), Changing Social Structure in Ghana, London, International African Institute.

Meyer, B. (1992), "If You Are a Devil You Are a Witch and If You Are a Witch You Are a Devil": The Integration of "Pagan" Ideas into the Conceptual Universe of Ewe Christians in Southeastern Ghana', Journal of Religion in Africa, 22(2) 98-132.

Meyer, B. (1995), 'Translating the Devil. An African Appropriation of Pietist Protestantism: 'The Case of the Peki Ewe in Southeastern Ghana, 1847-1992', unpublished $\mathrm{PhD}$ dissertation, University of Amsterdam.

Meyer, B. (1998), "Make a Complete Break with the Past", Time and Modernity in Ghanaian Pentecostalist Discourse', in R.P. Werbner (ed.), Memory and the Postcolony, London, Zed Books, Postcolonial Identities Series.

Mikell, G. (1995), 'The State, the Courts, and Value: Caught Between Matrilineages in Ghana', in J. Guyer (ed.), Money Matters. Instability, Values and Social Payments in the Modern History of West African Communities, London, James Currey.

Nimako, K. (1993), 'Nieuwkomers in een gevestigde samenleving: Een analyse van de Ghanese gemeenschap in Zuidoost (Amsterdam). Gemeente Amsterdam', Report to Stadsdeel Zuidoost.

Peil, M. (1979), 'Host Reactions; Aliens in Ghana', in W.A. Shack and E.P. Skinner (eds), Strangers in African Societies, Berkeley, University of California Press.

Peil, M. (1995), 'Ghanaians Abroad', African Affairs, 94(376): 345-67.

Rouse, R. (1995), 'Questions of Identity. Personhood and Collectivity in Transnational Migration to the United States', Critique of Anthropology, 15(4) 35180.

Senah, K. (1997), Money Be Man, Amsterdam, Het Spinhuis.

Shami, S. (1997), 'Transnationalism and Refugee Studies: Rethinking Forced Migration and Identity in the Middle East', paper for the Elizabeth Colson Lecture, Oxford University.

Sudarkasa, N. (1997), 'From Stranger to Alien: The Socio-political History of the Nigerian Yoruba in Ghana, 1900-1970', in W.A. Shack and E.P. Skinner (eds), Strangers in African Societies, Berkeley, University of California Press.

Ter Haar, G. (1994), 'Standing up for Jesus: A Survey of New Developments in Christianity in Ghana', Exchange, 23(3) 221-40.

Ter Haar, G. (1998), Halfway to Paradise: African Christians in Europe, Cardiff, Cardiff Academic Press.

van der Geest, S. (1997), 'Money and Respect: The Changing Value of Old Age in Rural Ghana', Africa, 67(4) 534-59. 
van der Geest, S. (1998), 'Yebisa Wo Fie: Growing Old and Building a House in the Akan Culture of Ghana', Journal of Cross-cultural Gerontology, 13: 33359.

van Dijk, R. (1997), 'From Camp to Encompassment: Discourses of Transsubjectivity in the Ghanaian Pentecostal Diaspora', Journal of Religion in Africa, 27(2): 135-60.

van Dijk, R. (1998), 'Pentecostalism, Cultural Memory and the State: Contested Representations of Time in Postcolonial Malawi', in R.P. Werbner (ed.) Memory and the Postcolony, London, Zed Books, Postcolonial Identities Series.

van Dijk, R. (1999), 'The Pentecostal Gift: Ghanaian Charismatic Churches and the Moral Innocence of the Global Economy', in R. Fardon, W. van Binsbergen and R. van Dijk (eds), Modernity on a Shoestring: Dimensions of Globalization Consumption and Development in Africa and Beyond, Leiden, African Studies Centre, London School of Oriental and African Studies.

Werbner, R.P. (1989), Ritual Passage, Sacred Journey. The Process and Organization of Religious Movement., Washington, Smithsonian.

Wyllie, R.W. (1980), Spiritism in Ghana: A Study of New Religious Movements, AAR Studies in Religion, no. 21, Missoula, Scholars Press.

Yeboah, Y.F. (1986), 'The Crisis of International Migration in an Integrating West Africa: A Case Study of Nigeria and Ghana', Africa and Development/Afrique et Dévelopment, 11(4), 217-56.

\section{Notes}

1. Examples include the well-known International Central Gospel Church, the Global Revival Outreach Ministry, the Harvest Ministries International and the World Miracle Church. In some of these churches, their international approach is represented symbolically by placing near the pulpit the flags of each country in which branches have been established.

2. This is probably a conservative estimate of the total population. There is no way to obtain an accurate figure.

3. It appears that it has been and still is much easier for women than for men to move out of illegality and achieve a legal status of residence. This is because the illegal system of contract marriage has been more accessible for women than men. Women marry Dutch nationals legally, paying their husbands a fee for their willingness to enter a marriage contract. After a woman has fulfilled the requirements for permanent residence, she divorces her husband and can then remarry, this time a Ghanaian man, or she can bring her husband over from Ghana. Further details of this strategy are beyond the scope of this chapter

4. A pastor of the IWBC explained to Birgit Meyer that upon receiving a basket full of eggs, precious food during the prevailing economic crisis, he asked his wife to go down to the beach and destroy all the eggs at once.

\section{Religion, Migration and Wealth Creation in the Swaminarayan Movement ${ }^{1}$}

\author{
Rohit Barot
}

Although changes in the traditional nuclear forms of family are widespread in modern European societies, they are not necessarily universal or unilinear. In contrast to narratives on fragmentation and breakdown typically associated with modern family living, this chapter seeks to show how Indians retain an ideology of family in the context of migration in their adopted homes in the diaspora, increasingly forming transnational and globalized networks. One of the key factors that this chapter attempts to highlight is that the family cannot be treated in isolation from other social and cultural institutions.

To explain the relative stability and the persistence of the South Asian family as an institution, it is necessary to examine the family in relation to two different levels of community formation. Although they may conflate in practice, social community based on caste or jati can be distinguished from a religious and sectarian community. Both at the level of caste or jati and at the level of shared faith, group formation is corporate and exerts considerable influence on those who, through their family, are embedded in a community of multiple affiliations.

As the traditional nuclear family has given way to a whole range of different family forms from single parent to gay and lesbian families in European societies, it is useful to outline briefly the meaning that Indians attach to the word 'family'. In Indian languages that derive from Sanskrit, the words kutumb and parivar refer to an extended family consisting of a three-generation residential unit or a joint family typically consisting of a man, his wife and married sons. A nuclear family may be formed by a husband, wife and children sharing a common residence. The most important part of kutumb and parivar is the universe of kinship and affinity that gives a more corporate expression to a caste or jati collectivity. The 